Simone, AbdouMaliq. 2004a. For the City Yet to Come: Changing African Life in Four Cities. Durham: Duke University Press.

- - 2004b. People as Infrastructure: Intersecting Fragments in Johannesburg. Public Culture 16 (3): 407-29.

Snipe, Tracey. 1998. Arts and Politics in Senegal, 1960-1996. Trenton, NJ: Africa World Press.

\title{
Transformed from the Inside Out
}

\section{A Review of Joanna Grabski's Art World City}

Dak'Art, Biennale de l'Art Africain Contemporain, is built from within, not without, argues Joanna Grabski in Art World City: The Creative Economy of Artists and Urban Life in Dakar. The Dak'Art Biennale reflects the artists, the urban context in which they create, and art-world globalization. From this artistic activity, the art world is structured, even if an infrastructure of museums, auction houses, and gallery spaces is not readily apparent to visitors to Dakar. Senegal's first president, Léopold Sédar Senghor, supported the arts during his presidency, from 1960 to 1980, but state-supported institutions of arts and culture and their collections declined soon after, in the period of economic stagnation ushered in by economic liberalization. Institutions such as the library and museum of the Institut Fondamental d'Afrique Noire, the Théâtre National Daniel Sorano, the Manufacture Nationale de Tapisserie, the Musée Dynamique, the École Nationale des Beaux Arts, and the École Normale Supérieure d'Éducation Artistique struggled without state support. And yet today, Dakar is a thriving center for the visual and performing arts, as well as for literature and fashion. How this has come to be is the story that Art World City tells.

Like an ethnographer of art, Grabski weaves this book from insider narratives and experience in Dakar's art world. This is not a book about art and artists in Dakar as subject matter: it is, rather, about artists as collaborators, as critical, thoughtful interlocutors, whose own insights often create new critical perspectives, which run ahead of the extant scholarship. Grabski's insider perspective has produced an innovative book on three fronts.

First, Art World City presents the fieldsite not as a bounded community, city, or nation-state, or even an institutional site like a museum, but as constituted through a nexus of transactions in which artist and studio are at the center. She traces how these transactions are constituted and how they reveal the dynamics of Dakar's art scene and its intersections with global art-world trends. This perspective on art from the global south echoes Jean and John Comaroff's argument in Theory from the South, that "contemporary world-historical processes are disrupting received geographies of core and periphery, relocating southward—and, of course, eastward as well-some of the most innovative and energetic modes of producing value" $(2011,7)$. In Dakar, Grabski argues, new modes of producing value 
abound, from the studios where artists transact art, to the NGOs that patronize the arts and artists. The biennale and its location in Dakar thus provide a context for understanding new modes of value production in the art system from the south.

Second, the book analyzes transformations in Dakar over time (19982015). Through field-based collaborative research with artists, Grabski shows how their works of art are motivated by, and are the outcome of, dynamic urban life. She presents the shifting social and economic context of the city over time in which artists work and which gives meaning to their creations.

Third, the book relates the materials of artistic creativity to theoretical perspectives on materiality. Grabski analyzes the work performed by material objects in the visual culture of the city. She offers a sensual-as well as material and visual-ethnography of the relationship between artists and material culture.

\section{Art from the South}

According to Grabski, the art world city is "a multiscalar urban site for artistic production, mediation, and transaction" $(2017,3)$. In this site, creative work and transactions, the urban context, and global currents converge through exhibitions, narratives, and networks shaped in artists' studios. The network materializes, becomes visible and obvious, when journalists, artists, gallerists, buyers, artists, diplomats, and collectors come together. The art world city is the site where buyers and sellers interact and converge with "the many artistic propositions that engage the city's visual, material, and spatial fields" $(2017,3)$. Like Dakar itself, it "emerges from and is shaped by the opportunities of urban life" $(2017,3)$.

Grabski conceptualizes the global art world not as exclusively comprised of blockbuster museum exhibitions, biennales, and art fairs, all of which characterize Europe and North America, but, rather, in the very making and transacting of art: "in Dakar, far more artists earn their livelihoods from making and selling art than are known to the curators, critics, or decision makers associated with global art world institutions" $(2017,11)$. Grabski effectively widens the reader's understanding of the global art world by focusing on the international workshops, residencies, and sales of artwork to globally connected buyers-NGOs, embassies, corporations.

The book covers a period of unprecedented economic liberalization in Senegal, from the 1990s on, and declining state patronage of the arts. For this reason, art transactions unfold in novel spaces, like corporations and NGOs, which have taken the place of the state. Dakar-based artists mount their own exhibitions and sell their own art. The studio has become more important than the gallery or the curator. In many ways, the art economy operates like other unregulated economic spaces of production that thrive outside of state intervention. Thus, Grabski situates her analysis of the arts in the context of the city in the global south and the unregulated economic spaces within it. 


\section{The Creative Context of Dakar}

Popular discourse about African cultural production imagines that innovation results from a scarcity, emergency, or abjection that seems to characterize the African continent (Ferguson 2006). Grabski takes up this critical perspective in Art World City, as do my colleagues Anne Marie Makhulu and Stephen Jackson in our book, Hard Work Hard Times, Global Volatility and African Subjectivities (2010). Grabski offers the example of European visitors to Dak'Art who ask if la récupération, a mode of creative activity involving salvaged and repurposed materials from the urban environment, emerged from the lack of art supplies and materials in the region. Here Grabski insists that this artistic movement does not emerge from a reaction to deprivation, a lack of materials, or necessity, but that la récupération is driven by a "particular type of visuality, a disposition to looking, prospecting, speculating" $(2017,147)$. Dakar's unregulated and improvised expansion in the context of economic liberalization provides a rich spectacle for the creative eye. Spaces like Colobane market-it is difficult to discern where the market ends and the street begins-present visually rich and dense displays of goods and discarded items. In such interstitial spaces, where the line between the official and unofficial blurs, artists create meaning. Dakar is both the context and the consequence of this activity, and Dak'Art provides a global platform for it.

From this standpoint, Art World City analyzes the relation between the urban environment and creative innovation. Grabski's approach builds on and extends that of Allen F. Roberts, Mary (Polly) Nooter Roberts, Gassia Armenian, and Ousmane Guèye, whose work A Saint in the City: Sufi Arts of Urban Senegal (2003) takes up Murid visuality in relation to Senegal's urban centers of Tuba and Dakar. Like those authors, Grabski sees urban space as both the context and condition of artistic inspiration. "[U]rban experience as predicated on and contoured by visual experience" $(2017,16)$ is central to Grabski's analysis of artistic practices.

As in Krista Thompson's book Shine (2015), on visual arts and Black diaspora contexts of performance, Grabski connects contemporary visual art in Dakar to popular art and culture in the urban capital. Thompson reminds us that central to vision is light and that artists are as concerned with the aesthetics of light as they are with being in the limelight, with seeing and being seen. Similarly, Grabski argues that in Dakar, buyers and sellers of all orders size each other up; they know how to look and how to be seen. This is often the role of the gallery, to size up buyers-a concept Grabski deftly describes with respect to artists in Dakar, whose studios perform many of the operations of galleries. Her film Market Imaginary (2013) likewise shows this process at various sites, from the stalls of secondhand goods in Colobane market, originally built on the outskirts of Dakar; now with urban sprawl its position has become more central to the transactional spaces of artists' studios. 


\section{Of Materials and Materiality}

Finally, Art World City breaks new ground by relating the materials of art to theoretical perspectives on materiality.

Like figures described in Jane Guyer's Marginal Gains (2004), who operate in both regulated and unregulated spaces of the economy at the same time, Grabski's artist-collaborators have devised similar stances for contending with economic volatility over the longue durée. Dakar's artists have been getting by in tough times by moving between transacting art in institutional frameworks, such as sites of state sponsorship of the arts, in OFF exhibitions organized alongside the official Dak'Art exhibition and in the space of their studios.

Another way in which artists in Dakar contend with long-term volatility is through the materials with which they create art. While arguing that the value of art is greater than the sum of its materials, Grabski engages in close analysis of materials themselves.

Consider, for example, the installation by sculptor Ndary Lo (19612017) shown in figure 1. From among the heaps of secondhand goods for sale

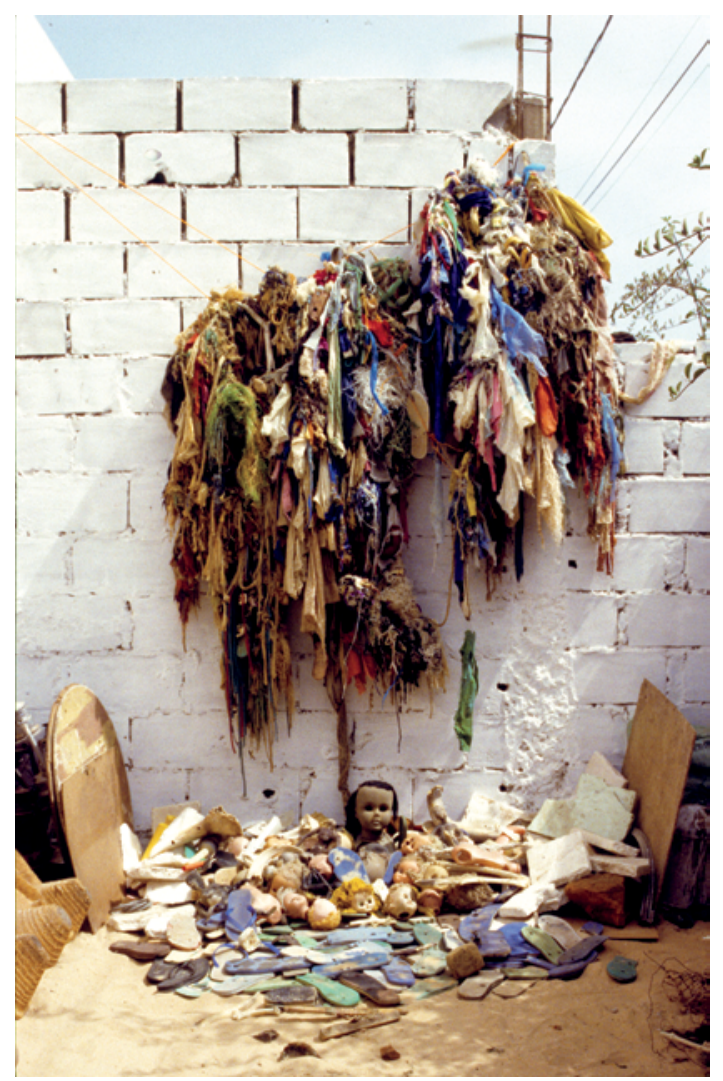

Figure 1. A mixed-media installation by Ndary Lo, Untitled, 2000. Photo by Joanna Grabski. 


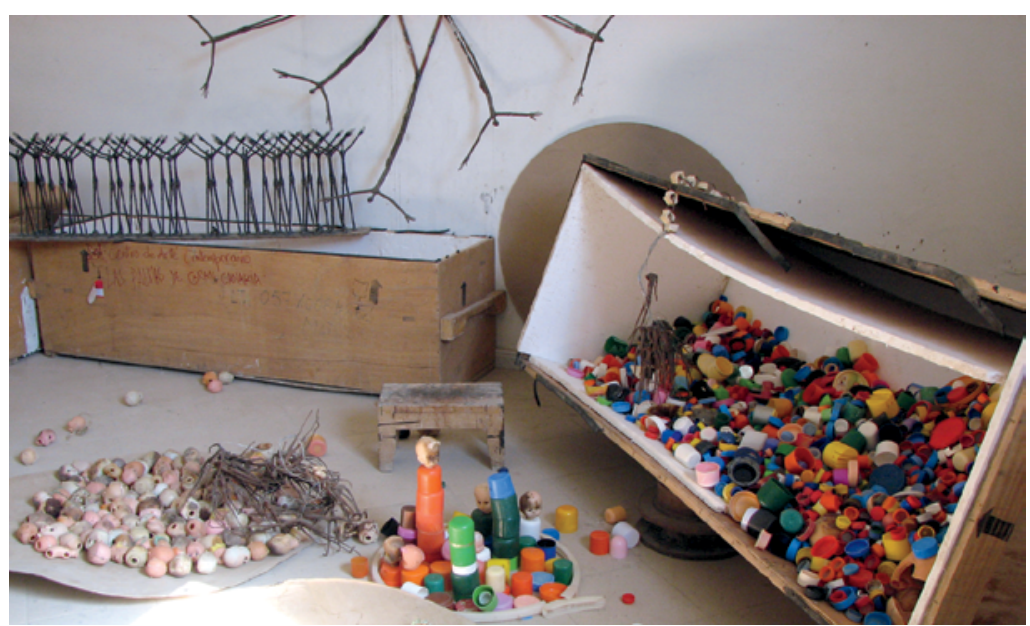

Figure 2. A corner of Ndary Lo's studio with plastic caps, metal, and doll's heads, January 2011. Photo by Joanna Grabski.

in Dakar's Colobane market, Lo selects plastic heads from dolls for his installation, as shown in figure 2 . He understands the qualitative complexities of these objects, at once commodity, profuse, interchangeable, and disposable, while they are part of the visual culture of Dakar's secondhand markets. Inspired by the material itself and the visual culture of the city, Lo deftly creates a singular work of art that transcends the commodity value of the objects of which it is comprised.

In her book and her film, Grabski suggests that art sits at the interface of a host of incommensurate values. How she captures what artists make of that difference is what makes Art World City such an innovative work. It shows how artists have transformed Dakar from the inside out into a global site for contemporary visual art. Grabski has given us a reinterpretation of artistic production and the marketing of art in the Global South that makes us rethink what we know of this city and of the art world writ large.

Beth Anne Buggenhagen

Indiana University Bloomington

\section{REFERENCES CITED}

Comaroff, Jean, and John Comaroff. 2011. Theory from the South:Or How Euro-America Is Evolving toward the South. New York: Routledge.

Ferguson, James G. 2006. Global Shadows: Africa in the Neoliberal World Order. Durham, NC: Duke University Press.

Grabski, Joanna, dir. 2013. Market Imaginary. Bloomington: Indiana University Press. DVD.

- - - 2017. Art World City: The Creative Economy of Artists and Urban Life in Dakar. Bloomington: Indiana University Press. 
Guyer, Jane I. 2004. Marginal Gains: Monetary Transactions in Atlantic Africa. The Lewis Henry Morgan Lectures 1997. Chicago: University of Chicago Press.

Makhulu, Anne-Maria, Beth Buggenhagen, and Stephen Jackson. 2010. Hard Work, Hard Times: Global Volatility and African Subjectivities. Berkeley: University of California Press.

Roberts, Allen F., Mary Nooter Roberts, Gassia Armenian, and Ousmane Guèye. 2003. A Saint in the City: Sufi Arts of Urban Senegal. Los Angeles: Fowler Museum of Cultural History, UCLA.

Thompson, Krista. 2015. Shine: The Visual Economy of Light in African Diasporic Aesthetic Practice. Durham, NC: Duke University Press.

\section{Dakar and Contemporary Art Criticism}

\section{A Review of Joanna Grabski's Art World City}

Art World City is a careful examination of the networks, substances, circumstances, and configuration of the art world in Dakar, Senegal. It is unique among studies of art in Senegal, whose primary interpretive lens has been nationalism. It broadens the field of urban studies, which has so far downplayed the art sector. If, as some urban theorists have argued, the world is one enormous city, then parsing how artists interface with international galleries, exhibitions, and collectors is a key aspect of describing how artists practice art in Dakar. Urbanism and its cultures have been a focus of scholars like Saskia Sassen for more than twenty years, but urbanism, which has seemed to stress the context of art more than art itself, has been slow to be adopted in art history. Art World City does both. It joins other compelling books, such as Achille Mbembe and Sarah Nuttall's Johannesburg: The Elusive Metropolis (2008), that imbricate the conceptual and tectonic layers of the city.

Art World City is part sociology and part art world exposé. It is unsystematic in its analysis of Dakar, but it emphasizes from the beginning that Dakar is unusual in the art world for the level of its use of the city as a stage for visibility; the term in Dakar is animation artistique. Grabski, in her introduction, writes that art events "were gathering sites where the city's art scene-artists, journalists, critics, animateurs d'art, diplomats, and collectors-made itself visible" (1). Joe Ouakam, the legendary and recently deceased Dakarois artist, is emblematic in this regard: Grabski explains that his whole persona as an artist was caught up in his visibility, to the extent that his presence eclipsed his art. From the chapter on visibility, Grabski is more specific about the nature of encounters, whether in artists' studios, the Dak'Art Biennale, galleries, and so forth. In a few sections, she moves into the interpretive mode of specific works of art-which contrasts with the overall thrust of the book.

Art World City was not written, however, in the service of globalist theory. Instead, and this is due to her obvious networking skills, Grabski presents readers with an insider's view of Dakar and its art scene, the granular aspects of its working, and demonstrates Dakar's distinction from the art worlds of other cities. Those of us who work on contemporary art know how 